\title{
How does disclosure of the HIV positive status modify drug use?
}

\author{
Adrian Octavian Abagiu ${ }^{1,2^{*}}$, Florin Matache Dună', Elena Daniela Bunescu', loana Cristina Fierbințeanu ${ }^{2}$, \\ Dan Popescu ${ }^{2}$, Rafael lanoş-Rancovici ${ }^{2}$, Anca Gubăr ${ }^{2}$, Poliana Ortansa Radu \\ From The 9th Edition of the Scientific Days of the National Institute for Infectious Diseases Prof Dr Matei Bals \\ Bucharest, Romania. 23-25 October 2013
}

\section{Background}

We wanted to examine how disclosure of the HIV positive status modifies risky behaviors and drug use in patients in substitution at the ARENA center from the National Institute for Infectious Diseases "Prof. Dr. Matei Balş", Bucharest.

\section{Methods}

The prospective study enrolled 94 patients diagnosed with HIV after IV consumption of "legal highs" and being in oral substitution treatment since March 2012. The final analysis included 71 patients who were in treatment in the range of 15 months from the initiation of the study and answered at least 2 of the quarterly surveys. All patients had urine tests done monthly.

\section{Results}

13 of the patients (18.3\%) were women; the average age was 31.2 years with an average IV drug use of 8.7 years, of which 19 months with legal highs also. The average number of relapses per patient prior to the study period was 4.7, due to lack of participation to psychotherapy. Only 17 patients (24\%) managed to quit legal highs consumption in the studied period. 15 patients $(21 \%)$ were out of therapy for a period of over 21 days within the study period. Most of them are with low literacy (6.2 grades), 91\% were incarcerated. Of the 24 patients in antiretroviral treatment, 3 dropped out of therapy. Only 7 patients had positive urine test for opiates, but other 47 had recognized legal highs intermittent consumption.

\footnotetext{
* Correspondence: adyaba@gmail.com

${ }^{1}$ National Institute for Infectious Diseases "Prof. Dr. Matei Balş", Bucharest, Romania
}

Full list of author information is available at the end of the article

\section{Conclusion}

Paradoxically, disclosing the HIV-positive status, with all the counseling and even involving free access to substitution therapy, caused relapse in the majority of patients. The main idea is that if they are going to die, at least to die "drugged and happy". On the other hand this signals the need for new approaches in counseling.

\section{Authors' details}

'National Institute for Infectious Diseases "Prof. Dr. Matei Balş", Bucharest, Romania. ${ }^{2}$ Romanian Anti-AIDS Association (ARAS), Bucharest, Romania.

Published: 16 December 2013

doi:10.1186/1471-2334-13-S1-P18

Cite this article as: Abagiu et al: How does disclosure of the HIV positive status modify drug use? BMC Infectious Diseases 2013 13(Suppl 1):P18.

Submit your next manuscript to BioMed Central and take full advantage of:

- Convenient online submission

- Thorough peer review

- No space constraints or color figure charges

- Immediate publication on acceptance

- Inclusion in PubMed, CAS, Scopus and Google Scholar

- Research which is freely available for redistribution

Submit your manuscript at www.biomedcentral.com/submit

\section{() Biomed Central}

C Biomed Central

C 2013 Abagiu et al; licensee BioMed Central Ltd. This is an Open Access article distributed under the terms of the Creative Commons Attribution License (http://creativecommons.org/licenses/by/2.0), which permits unrestricted use, distribution, and reproduction in any medium, provided the original work is properly cited. 